\title{
GEOTECHNICAL MAPPING AND ITS APPLICATION IN CITY PLANNING AND ASSOCIATED LEGISLATION
}

\author{
MAPEAMENTO GEOTÉCNICO E SUA APLICAÇÃO NO PLANEJAMENTO \\ DA CIDADE E NAS LEGISLAÇÕES ASSOCIADAS
}

BRUNO RODRIGUES DE OLIVEIRA Programa de Pós-graduação em Geotecnia, Universidade de Brasília, Distrito Federal, Brasil, brunorodriguesoli@gmail.com

YAMILA KHRISNA OLIVEIRA DO NASCIMENTO CUNHA Secretaria de Estado de Desenvolvimento Urbano e Habitação,

Distrito Federal, Brasil, millakhrisna@gmail.com

\begin{abstract}
RESUMO
The urbanization process should not aim to proper areas for urban expansion, but also the request of the environment for demands such as aggregates for civil construction and the availability of surface and underground water for human and animal supply. It is already well known that the urbanization process must consider geological, urbanistic, hydrological, climatological aspects, among others, but some current legislation disregard the importance of these themes. This research presents a history of the application of the urban geology to geotechnical cartography and a discussion of the legislation of Federal District that is related with the cartographic products of geotechnical cartography.

O processo de urbanização não deve almejar somente as áreas adequadas para a expansão urbana, mas também a solicitação do meio ambiente de demandas como agregados para construção civil e disponibilidade de águas superficiais e subterrâneas para o abastecimento humano e animal. Já é bastante conhecido que o processo de urbanização deve considerar aspectos geológicos, urbanísticos, hidrológicos, climatológicos, entre outras, mas algumas legislações vigentes desconsideram a importância dessas temáticas. Essa pesquisa apresenta um histórico da aplicação da geologia no meio urbano até a cartografia geotécnica e uma discussão acerca das legislações do Distrito Federal que tem relação com os produtos cartográficos da cartografia geotécnica.
\end{abstract}

Keywords: Urban Planning, Geotechnical Cartography, Applied geology.

Palavras-chave: Planejamento urbano, Cartografia geotécnica, Geologia aplicada. 


\section{INTRODUCTION}

"The number of possibilities for the application of geological knowledge in planning is very extensive and it is not worth to have pages just listing all of them." (Legget, 1973). However, geology is not the only science required in the planning process and, even with its increasing application and the notoriety of geosciences in harmonizing the changes caused by man and the environment, the applicability of the discipline in urban planning is still little known, mainly from the public.

Surface land is an expression of subsurface geology, so those involved in the planning process must understand the geological aspects (BELL, 2009). These statements make a lot of sense when it is noticed that cities are settled on deposits of residual or transported unconsolidated materials arising from the process of alteration of a given geological unit. In view of the above, several authors (LEGGET 1973; JEFFERIS 1986; SANTOS 2008; BELL 2009; CULSHAW \& PRICE, 2010; SANTOS, 2017) emphasize the need for knowledge of the geology of the area to be planned, which must be appreciated and incorporated into the process urban planning. However, the work of geologists in this process is unusual and there are several factors that lead to this situation.

It can be mentioned the lack of knowledge of the applicability of geology in urban planning by the professionals involved in city planning, or the inefficiency of geologists to demonstrate the relevance of its use as the main causes of the small role of geologists in this area (CULSHAW \& PRICE, 2010). This is aggravated by the fact that reports written by geologists have a technical focus on geology and are understood mainly by specialists in geology (CHAND, 1999).

The geologist who is dedicated to solving urban problems, working in the urban planning process, must necessarily have a broad technical and urban vision of the city, knowledge that is not included in the professional training of geologists (OLIVEIRA \& MONTICELLI, 2018). It is also important for the professional to be aware of the requests that different types of projects have on the land, which will allow him to guide the investigation campaign and the communication of results (SANTOS, 2008).
Add to the reasons the lack of vision by part of some professionals of the need for a multidisciplinary approach, both in the team working in the planning process, and in the aspects to be evaluated. Sometimes, the concentration of concerns and responsibilities, called "environmental" by planners, commonly leads to the general idea that all the rest of public organizations are uncompromising to consider these aspects on the grounds that this theme is not theirs.

Santos (2017) and Oliveira \& Monticelli (2018) report the importance of architecture and urbanism to adopt the principles of sustainability, since essential aspects related to serious and costly problems of geological-geotechnical nature are often related to the mismatches between architectural concepts and natural characteristics of the physical environment.

Considering the above, this paper aims to discuss the importance of geotechnical maps in urban planning and to identify the relationship, or the lack thereof, in legislation related to urban planning such as Master Plan for Territorial Planning (PDOT), Law of Land Use and Occupation (LUOS), Soil Installment Law and Ecological Economical oning (EEZ). The choice of the Federal Districtl (DF) as the object of study for evaluating legislation is due to the current PDOT / DF review process.

\section{URBAN GEOLOGY}

Urban geology is a specialty claimed by some geologists, whose area of expertise encompasses both regional geology and applied geology, which emphasizes the use of geological principles and knowledge to solve construction and environmental problems in urban areas or surroundings (KARROW \& WHITE, 1998).

According to Rodriguez (1998), urban geology deals with the geological, geomorphological, geotechnical and hydrogeological knowledge necessary to subsidize man's interventions in the urbanization process, producing the least possible impact.

Bathrellos (2007) corroborates the definition presented by Karrow \& White (1998) when 
defining urban geology as the application of geological knowledge for the planning and management of metropolitan areas. The author adds that the discipline involves subdisciplines that contribute to the definition of areas for waste disposal, delimitation of mineral deposits and identification of risk conditions, and points out that the geotechnical aspects are the competence of engineering geology.

Culshaw \& Price (2010) define urban geology as the study of the interaction between human and natural processes with the geological environment in urbanized areas, and the resulting impacts, and the provision of geoinformation that allows sustainable development, regeneration and conservation of cities. The authors do not define the types of knowledge involved or the purposes, but that the discipline must seek harmony between the urbanization process and the environment.

Based on the authors, urban geology is understood as the application of geological and related principles and knowledge to obtain geoinformation about the surface and subsurface conditions of the land, aiming to define land use and occupation guidelines. Such guidelines must be capable of reconciling the requests and demands of the urbanization process and the capacity to support the environment in order to avoid geotechnical and environmental problems, resulting in a sustainable and compact occupation process.

It is important to differentiate urban geology from geology performed in urban areas. Many geologists prefer to do geological mapping in less developed areas due to the little disturbance of the environment and the greater challenges related to working in urban areas, since the outcrops would only be available during excavations and would need a constant mobilization of researchers (SHOWSTACK, 2014). Research such as the definition of geological routes and the study of the geological elements present in buildings and monuments would also fall into the category of geology carried out in urban areas.

Bathrellos (2007) reports that, since the term Environmental Geology (GA) appeared, the terms Urban Geology (GU) and Engineering Geology (GE), which are areas derived from terminology, have been less used. GE is the science dedicated to the investigation, study and solution of engineering and environmental problems arising from the interaction between the works and activities of man and the geological physical environment, as well as the prognosis and the development of preventive or risk repair measures (SANTOS, 2008). GE, formerly called applied geology, received the name of Engineering and Environmental Geology (GEA), which operates in environmental management, in the implementation of infrastructure works, in urban and regional planning and in other specific technical areas (OLIVEIRA \& MONTICELLI, 2018), being the term currently used. A history of GEA is presented by the aforementioned authors, in which the consideration of environmental aspects associated with geological geotechnical aspects has become essential since 1986.

\subsection{History of urban geology to geotechnical cartography}

The application of geological knowledge in planning and construction dates from Babylonian times (LEGGET, 1973), however, one of the first works involving geologists in the urban environment was in 1843 in Great Britain, whose objective was to inquire about the state of cities and populous districts regarding public health (ANON, 1900 apud CULSHAW \& PRICE, 2010).

Culshaw \& Price, (2010) report that initiatives related to urban geology did not continue after the First World War due to the emergence of Soil Mechanics, despite Dearman (1991) exposing urban geological maps prepared in Germany. The elaboration of works in this area resumed after the Second World War, probably due to the emergence of the belief in urban planning (CULSHAW \& PRICE, 2010).

Urban geology began to develop in the 1950s, particularly in California, in relation to land use and occupation planning, whose experiences led Robert Legget to publish the book "Cities and Geology" in 1973, considered the main reference in this theme. In this decade, the applicability of geology in the urban planning process was recognized, making it essential to present 
information that contemplated aspects relevant to civil engineers, architects, geographers and other professionals working in urban planning.

Mulder (1993) presents an article reviewing the state of the art on urban geology in Europe and shows that studies have been developed since 1920 and that, in the 90s, there was a great deal of attention focused on the knowledge of geological conditions in the urban areas. The author notes that the increase in the use of hydrogeological and geotechnical models in the late 1970s made it possible to predict and quantify the effects of urban interference on the geosphere.

Davies (2015) presents a compilation of case studies in the largest urbanized African areas (Cairo, Lagos and Kinshasa) that discuss the assessment of the dynamics of geoenvironmental phenomena and the description and analysis of geological data in order to demonstrate the application of urban geology in the construction and Africa's development. Since the 1980s, the Association of Engineering and Environmental Geologists encouraged the publication of papers to document the development of urban geology, which varied in content and data quality.

Davies (2015) reinforces the application of geotechnical databases in civil construction to solve problems of a geological nature and, considering that engineering problems are related to local geology, the solutions adopted in a given area can be applied later in places with similar geological conditions.

In Brazil, according to Rodriguez (1998), the term Urban Geology was used for the first time at the 38th Brazilian Congress of Geology, naming one of the symposia of that event, which took place in 1994. However, applications of geological knowledge to urban problems have been found in the records of Brazilian Geology Congresses since the 1960s. The author also presents a history in the technical-scientific environment of the use of geology in city planning in the 80s and 90s that demonstrates an increase in the number of works related to urban Geology, presented at geological congresses of the Brazilian Society of Geology, between 1967 and 1996.

In later years, attention was turned to geotechnical cartography applied to urban planning, which ended up becoming one of the main instruments used for this purpose, even though in the 70s and 80s, in several works, there was a concern turned to geotechnical maps with this objective (PELLOGIA, 1997).

Pellogia (1997) indicates that at least $60 \%$ of the works at the 1st Brazilian Symposium on Geotechnical Cartography, in 1993, dealt with the theme of urban planning. Tominaga et al. (2004) and Paula \& Cerri (2008) state that most of the maps produced aim to guide urban and regional planning and the Federal Districtdoes not escape this rule. In the following topics, a better detail about this instrument and its importance will be elaborated.

The geotechnical cartography applied to urban planning became so big that the Brazilian Geological Service (SGB) or also known as the Mineral Resources Research Company - (CPRM), adopted geotechnical maps as one of the main instruments used to assist in spatial planning. Unfortunately, this fact only occurred due to the occurrence of natural disasters in Brazil, especially in the 2010s, which led to awareness of the importance of using geotechnical maps in urban planning, whose obligation was established in Law No. 12,608 of April 10, 2012 (BRASIL, 2012).

\section{GEOTECHNICAL CARTOGRAPHY}

The geotechnical chart is an essential basic tool for the prevention and correction of situations related to natural and technological disasters (COUTINHO, 2013). It also has the important role of making communication between geologists and planners allowing aspects of the environment to be considered during planning.

According to Prandini et al. (1995), geotechnical maps are products of the application of geological knowledge in solving problems related to land use and cover, in addition to serving as a basis for the development of preventive or corrective measures in order to reduce environmental problems and risks to enterprises.

The geotechnical chart synthesizes the knowledge about the physical environment and its active processes (geo) in a given area, in order to assist the development of measures for the 
adequate occupation of the soil (technique). This chart therefore constitutes a product resulting from the need to characterize the land, committed to an intervention or solution for the use and occupation of the soil. Therefore, the land units are delimited, whose zoning establishes the division of the soil into homogeneous areas or domains (COUTINHO, 2013).

Geotechnical maps provide information on the components of the physical environment and the local that are significant to the purpose of the chart and that help the relationship between man and the environment without causing negative impacts to both parties. It is important that the cartographic products are clear and objective and serve as a guide for later stages of investigations (OLIVEIRA, 2018) in addition to being capable of understanding by other professionals.

For geotechnical maps, whose purpose is urban planning, its elaboration is commonly carried out at the scales 1: 100,000 to $1: 10,000$, for places where the expansion activity occurs in a disorderly, inadequate manner or in places with several available research data. However, the use of scales between 1: 2,500 and 1: 1,000 is the most recommended (DEARMAN, 1991).

In municipal regional maps, intended for land use planning and management and which rarely use quantified geological-geotechnical parameters, a scale of representation of 1: 25,000 is recommended. In the detailed maps, aimed at fitness and urbanization, on scales 1: 10,000 or greater, the quantification of parameters is expected. Both are, with different scope, one of the fundamentals for the elaboration of the methodological strategy that meets the National Program for Risk Reduction and Disaster Response (COUTINHO, 2013).

Following Coutinho's (2013) proposal, the Brazilian Geological Service adopted three scales for the elaboration of maps applied to urban planning based on the progressive detailing methodology. The maps are drawn up at scales 1: 25,000 for assessing susceptibility to gravitational mass movements and floods, 1: 10,000 for defining aptitude for urbanization and 1:2,000 or greater for risk assessment, each with a purpose different.

In addition to the scale and purpose of geotechnical maps, methodology is also a very important factor to be considered. Some methodologies have been proposed to serve specific purposes while others have general procedures and can be adapted, depending on the purpose. It is worth mentioning that, regardless of the methodology adopted, some aspects such as geology, soils, surface and underground waters, anthropic actions, geomorphology and geodynamic phenomena are fundamental for the elaboration of a geotechnical chart.

\section{LEGISLATION ASSOCIATED WITH GEOTECHNICAL CARTOGRAPHY IN THE FEDERAL DISTRICT}

Urban planning, especially when developed in accordance with the regulation of land use, is essential for cities in order to control urban expansion (FELTRIN \& RAIA JUNIOR, 2013). Article 4 of Law No. 10,257 of July 10, 2001 (BRASIL, 2001), known as the City Statute, defines a series of instruments that must be taken into account when the objective is to achieve adequate urban planning. Among the existing urban policy instruments, some affections to the Federal Districtand some Federal Laws that are directly related to urban planning will be presented and the applicability and its relationship with geotechnical maps will be discussed.

\subsection{Law n ${ }^{\circ} 12,608$ of april 10, 2012}

Law No. 12,608 / 2012 (BRAZIL, 2012a) institutes the National Policy for Civil Protection and Defense (PNPDEC) which aims to integrate into the policies of territorial ordering, urban development, health, environment, climate change, resource management water, geology, infrastructure, education, science and technology and other sectoral policies, with a view to promoting sustainable development (BRASIL, 2012).

In addition to other measures, the Law determines preventive instruments, among them, the mapping of areas at risk to mass gravitational movements and flooding and the elaboration of geotechnical maps for urbanization, both large-scale cartographic products, which must 
presented in the next review of the Master Plan.

Article 22 of Law No. 12,608 / 2012 (BRASIL, 2012), amends Law No. 12,340 / 2010 (BRASIL, 2010), establishing that municipalities must prepare the geotechnical charter for urbanization, defining urban guidelines aimed at the security of new land installments.

Among one of the articles that have been changed, Art. 42 can be cited, which defines that the Master Plan must contain at least the delimitation of the urban areas where compulsory subdivision, building or use can be applied, considering the existence of infrastructure and demand for use, in the form of Art. 5, provisions required by Arts. 25, 28, 29, 32 and 35, of a monitoring and control system (BRASIL, 2001).

In addition to the content provided by the art. 42, due to Law No. 12,608 of April 10, 2012 (BRASIL, 2012), the Master Plan dos Municípios included in the national register of municipalities with areas susceptible to the occurrence of high impact landslides, sudden floods or related geological or hydrological processes should to contain:

\section{$[\ldots]$}

II - mapping containing the areas susceptible to the occurrence of high impact landslides, sudden floods or related geological or hydrological processes;

III - planning preventive intervention actions and relocating the population to areas at risk of disaster;

IV - urban drainage measures necessary to prevent and mitigate the impacts of disasters;

[...]

$\S 1$ The identification and mapping of risk areas will take into account the geotechnical maps. $[\ldots]$

In order to fulfill the demand defined in item II, the Geotechnical Charter for Susceptibility to Geodynamic Phenomena is necessary, a cartographic product that allows the identification of suitable areas with restrictions on occupation in the face of natural disasters.

As for items III and IV, in order to properly plan structural interventions, the planner needs a Risk Chart that aims to reduce or eliminate risk situations in the short term, in addition to subsidizing risk planning and management instruments and assisting in the adoption of engineering solutions, structural or non-structural interventions.

The national register of municipalities with areas susceptible to the occurrence of high impact landslides, sudden floods or related geological or hydrological processes has not yet been established. However, areas of risk to geodynamic phenomena similar to the aforementioned ones were identified in academic research (BATISTA, 2014) and by the Civil Defense in 2015 and 2016, underscoring the need to prepare cartographic products.

\subsection{Soil installment law}

Law No. 6766 of December 19, 1979 (BRAZIL, 1979) provides that the Land Installment for urban purposes can only be done through subdivision or dismemberment, subject to the provisions of this Law and those of the relevant state and municipal laws. Allotment is the subdivision of land in lots for the building, with the opening of new traffic routes, public places or extension, modification or expansion of existing roads.

The cases of prohibition on the subdivision of urban land are presented in Art. 3, which defines that only the subdivision of land for urban purposes in urban areas, urban expansion or specific urbanization, as defined by the Master Plan or approved by municipal Law, will be allowed. The same article lists the prohibitions on land parceling in the form of items:

I - in wetlands and subject to floods, before taking steps to ensure the drainage of water;

Il - on land that has been filled with material harmful to public health, without being previously sanitized;

III - on land with a slope equal to or greater than $30 \%$ (thirty percent), unless specific requirements of the competent authorities are met;

IV - in lands where geological conditions do not advise the building; and

$\mathrm{V}$ - in areas of ecological preservation or in those where pollution prevents bearable sanitary conditions, until their correction.

Items I and IV are directly related to the Chart of Susceptibility to Gravitational Movements of Mass and Floods, which classifies the lands 
in different degrees regarding the propensity to physical processes that can generate disasters, and to the Geotechnical Chart of Aptitude to Urbanization, which contains the result of an assessment of the hazards associated with physical processes and recommendations for urban land use according to the limitations and potential of each delimited geotechnical unit, in addition to the Hazard and Risk Maps that are the result of risk analysis, pointing out sectors and buildings in situations of higher or lower risk (BITAR et al. 2015).

Regarding item III, a simple routine in a GIS is able to identify areas with slopes higher than the limit defined in the law, however the section "unless specific requirements of the competent authorities are met" generates two questions: What are these requirements? And what are the instruments that define them? In the Master Plan de São Paulo (PDOT-SP), the requirements are defined by the geotechnical maps, which in turn are provided for in the National Plan for Risk Management and Response to Natural Disasters (BRASIL, 2012).

The Urbanization Aptitude Charter further states that the approval of the Allotment and Dismemberment project, in the municipalities included in the national register of municipalities with areas susceptible to the occurrence of high impact landslides, sudden floods or related geological or hydrological processes, will be linked to the fulfillment of the requirements contained in the chart (Paragraph 2 of Article 12).

Ecological Economical Zoning (ZEE)

Ecological Economical Zoning of Federal District - ZEE-DF is a strategic instrument for territorial planning and management, whose guidelines and criteria begin to guide district public policies aimed at sustainable socioeconomic development and improving the quality of life of the population (BRASIL, 2019a).

ZEE-DF, Law No. 6269, of January 29, 2019 (BRASIL, 2019a), established a zoning of risks, both ecological and socioeconomic, which must be considered for the definition of zoning of uses, within the scope of planning and territorial management. Among the objectives of the Law provided for in Article 5, items V and VI stand out, transcribed below:
$\mathrm{V}$ - incorporate the assessment of ecological risks in formal planning instruments and public and private management to guarantee the integrity of ecosystems;

VI - to guide public and private agents regarding the observance of the environmental support capacity, in the elaboration and execution of public policies;

[...]

IX - preserve and protect the waters in the territory of the Distrito Federal, promoting management and management actions aimed at stabilizing or raising water levels in aquifers and improving the quality and quantity of surface water, recognizing and valuing its various dimensions, uses multiple and the distinct visions and values associated with them as the birthplace of waters in three Brazilian hydrographic basins;

$[\ldots]$

The ecological risks listed in item $\mathrm{V}$ and defined as relevant were: Ecological Risk of Loss of Aquifer Recharge Area in the Distrito Federal; Ecological Risk of Soil Loss from Erosion in the Distrito Federal; Ecological Risk of Subsoil Contamination in the Distrito Federal; and the Ecological Risk of Loss of Remaining Native Cerrado Areas in the Distrito Federal.

Regarding item VI, there is a special importance when it mentions "guiding public and private agents regarding the observance of the environmental support capacity", emphasizing the need for consideration of the environment in planning.

Item IX highlights the concern with the water availability of the DF, which is directly related to the recharge of aquifers, which, in turn, depends on the infiltration capacity, permeability and soil coverage, aspects that can be addressed in geotechnical maps if requested by the Government.

Finally, when talking about urban areas, there are other risks commonly associated with geodynamic phenomena or occupations in inadequate areas. As previously said, geotechnical maps are essentially the application of geological knowledge in solving problems related to land use and it is up to planning, through instruments such as the Master Plan de Ordenamento Territorial (PDOT), the presentation of these cartographic products and the addressing these issues. 


\subsection{Master Plan for Territorial Planning of Federal District (PDOT/DF)}

Master Plan is a basic instrument of urban development and expansion policy which must be reviewed at least every ten years. The City Statute (BRASIL, 2001) defines Master Plans as being mandatory for cities with a population above 20 thousand inhabitants and can be defined as a set of principles and guidelines that guide the use of urban space (FELTRIN \& RAIA JUNIOR, 2013).

In DF, PDOT was instituted by Complementary Law n ${ }^{\circ}$ 803, of April 25, 2009 (BRASIL, 2009) and updated by Complementary Law n $\mathrm{n}^{\circ} 854$, of October 15, 2012 (BRASIL, 2012b).

Article 37 of the PDOT presents the guidelines for urbanization and land use and occupation:

I - the establishment of more compact urbanized areas in the territory;

II - structured urbanization along the main connecting infrastructures, with increasing demographic densities along the structural road network;

III - the expansion of urban land in continuity with the existing urban centers and in transition with rural areas that suffer urban pressure, observing the capacity of socioeconomic and environmental support of the territory;

IV - avoid the segregation of uses, promoting their flexibility, in order to reduce displacements and balance the distribution of places of employment and work in the Federal District;

$\mathrm{V}$ - promote the integration of residential subdivisions distributed in a dispersed and fragmented manner in the territory among themselves and with the neighboring consolidated urban centers;

VI - stimulate the occupation of residual voids in urbanized areas endowed with services, infrastructure and equipment, preferably the creation of new urban areas, in order to optimize the capacity of the installed infrastructure and reduce urbanization costs, observing the environmental conditions of the territory;

VII - propose and admit new forms of urbanization;

VIII - to enable the occurrence of different architectural types and facilitate the adaptation of buildings to new uses;

IX - progressively reduce the urban social deficit represented by the lack of urban infrastructure, social services and housing, through investments and the application of the legal, tax and financial instruments provided for in this Complementary Law.

Single paragraph. Only the occupation of areas that do not have environmental restrictions will be allowed, observing the specific legislation for environmental licensing.

This aforementioned article does not present specific guidelines related to the prohibition on the occupation of environmentally vulnerable and risky areas, or on the environmental support capacity, which is currently supplied by the ZEE-DF. However, in Art. 191, transcribed below, which deals with the granting of special use for housing purposes, areas that present a risk do not mention the use of any cartographic product that supports the application of the article.

Art. 191. Areas that present a risk to the safety of the population or an environmental risk are not eligible for special use for housing purposes. Single paragraph. Risk areas are considered for the purposes of this Complementary Law:

I - areas whose geological and topographic characteristics present a risk to the resident, such as geotechnical instability related to landslides, rupture of massif and erosion, or risk of fire, postfire impacts and risk of flooding;

II - areas whose degradation could compromise the resources and environmental quality of the region, representing a risk to the community, and which cannot be solved through works.

In this sense, geotechnical maps of susceptibility, aptitude for urbanization and risk allow the identification of areas unsuitable for urban and risky occupation, which would be a tool of great importance for planners in the effective application of the aforementioned article.

Among the types of geotechnical maps, the aptitude for urbanization is the most appropriate choice because they are designed to stimulate urban development in safe locations, combating the occupation of environmentally vulnerable and risky areas. In the case of areas already occupied, risk maps will be more appropriate depending on their level of detail.

\subsection{Law of Land Use and Occupation (LUOS)}

The Law of Land Use and Occupation of Federal District, Complementary Law No. 
948, of January 16, 2019 (BRASIL, 2019b), is the complementary instrument of the territorial planning and urban expansion and development policies of the Federal District. This Law establishes the criteria and parameters for land use and occupation for plots and projections located in Urban Macrozone of the DF and in the urban subdivisions registered in a real estate registry office, implemented and / or approved by the government.

Chapter V of this Complementary Law deals with the use and occupation in urban land parceling projects, new or land regularization, however, at no time mentions the need to assess environmental capacity, or the existence of risk areas as one of the criteria permission to occupy a particular region.

Given the importance and scale of application of LUOS, aspects other than urban planning should be considered in its preparation and application. Permission to use the subsoil should consider aspects such as excavation, while, for lots that present some risk, the permission to use should only be granted in cases where the necessary measures are taken.

The current text of LUOS was designed only for the regularization of existing uses in the territory and does not seek integrated development with environmental protection.

\subsection{Urbanistic guidelines}

The Urbanistic Guidelines will be issued by the managing body of the territorial and urban development of the Federal District, considering the provisions contained in the current PDOT and the established in art. 6 of Federal Law $\mathrm{n}^{\mathrm{o}} 6.766$ / 1979 (BRASIL, 1979), and more restrictive conditions can be established through environmental and urban studies (BRASIL, 2009).

The Guidelines have a validity period of 4 (four) years, and may be reevaluated in a shorter period, according to public interest or unless changes in legislation that imply alteration of land use and occupation happen. The document presents at least the principles of urbanization, the Road System and Circulation Guidelines, Land Use and Occupation, Population Density, Public Areas, Urban Design, Urban Infrastructure, in addition to a characterization of the environment and other information related to the area of study.

The Guidelines guide the use and occupation of land in order to constitute an integrated urban space, composed of articulated parcels and which complement each other in the offer of uses and activities, contributing to the quality of life of the population. They are a prerequisite for beginning the process of regularizing occupied areas and for the authorization of new installments, and consider all the aforementioned legislation.

Among the Urbanistic Guidelines, only the updating of the Taquari Housing Sector Guidelines - Stage II, still in the elaboration stage, used information from a geotechnical chart in its elaboration.

\section{CONCLUSIONS}

In view of all the discussion presented here, it was possible to realize that the planning and urbanization process, despite having an extensive legal framework, needs to appropriate a much broader approach than just "urban expansion". The concern with the environment, characterization of the geological-geotechnical, availability of surface and underground water for supply, better techniques of civil construction, and quality of life of the population must be priority of an adequate urban planning.

We reinforce the importance of multidisciplinarity during planning, not only of Geology, but also of Urbanism, Hydrology, Climatology, among others. Each author sought to disseminate this knowledge with their respective approaches, but all converge to the application of geological knowledge aiming at sustainable development or the non-exposure of the population to risk situations.

However, it is not uncommon for this information to be presented in raw form, that is, without proper interpretation for urban planning purposes. Thematic maps that present information about the geology, geochemistry of rocks, soils and waters, geotechnical properties of soils and rocks, mineral resources, especially building materials, geotechnical classification of slopes, landslides, areas prone to flooding, flow pattern groundwater, and others, are examples of 
extremely important raw information, however it is necessary to translate these aspects into derived maps, which will be easier for planners and managers to use.

Thus, the importance of geotechnical cartography in urban planning is emphasized. In addition, the current legislation on the subject could benefit from the cartographic products already mentioned. The maps must be drawn up on the scales: 1: 25,000 for the assessment of susceptibility to gravitational mass movements and floods, which can be used to restrict areas subject to occupation; 1 : 10,000 for the definition of aptitude for urbanization, which can be used for the most diverse purposes, from choosing suitable places for urban expansion to identifying places that must be preserved in order to use natural resources (eg natural materials construction, water resources, among others); and 1: 2,000 or greater for risk assessment that can be used to identify buildings in situations of risk, places where structural and non-structural interventions are needed, among others.

Eight years after the approval of Law No. 12,608 / 2012, the national registry of municipalities with areas susceptible to the occurrence of high impact landslides, sudden floods or related geological or hydrological processes has not yet been instituted. Even so, these cartographic products are widely used in the technical scientific environment. Although the Federal Districthas at least nineteen researches between master's dissertations and doctoral theses, six of which since the approval of the Law, related to geotechnical cartography, none of these works were considered in the Law of ZEE, LUOS and the review process of the PDOT.

Therefore, planners are recommended to multidisciplinarize and qualify the teams responsible for the preparation of these cartographic products or to hire an outsourced team to perform the service. A possible alternative is to strengthen the relationship between the public service and the academy, since these cartographic products can be the result of cooperation between researchers and the government.
We thank the geotechnical postgraduate program at the University of Brasilia.

\section{REFERENCES}

BATISTA, P.H.L 2014. Cartografia geotécnica aplicada aos riscos de alagamento e inundação na bacia do rio São Bartolomeu. 2014. xix, 223 f., il. Dissertação (Mestrado em Geotecnia) Universidade de Brasília, Brasília, 2014.

BATHRELLOS G.D. 2007. An overview in urban geology and urban geomorphology. Bulletin of the Geological Society of Greece vol. XXXX, 2007. Proceedings of the 11th International Congress, Athens, May, 2007, 11 p.

BELL. F.G. 2009 Environmental Geology and Planning. Geology In: editado por Benedetto De Vivo, Bernhard Grasemann, Kurt Stüwe. Geology Vol. V. Encyclopedia of Life Support Systems (EOLSS), 457 p.

BRASIL 1979. Lei $n^{\circ}$ 6.766, de 19 de dezembro de 1979. Dispõe sobre o parcelamento do Solo Urbano e dá outras Providências. Diário Oficial da República Federativa do Brasil, Brasília, DF, 11 p.

BRASIL. 2001. Lei n ${ }^{\circ} 10.257$, de 10 de julho de 2001. Regulamenta os arts. 182 e 183 da Constituição Federal, estabelece diretrizes gerais da política urbana e dá outras providências.

BRASIL 2009. Lei Complementar n. ${ }^{\circ}$ 803, de 25 de abril de 2009. Aprova a revisão do Plano Diretor de Ordenamento Territorial do Distrito Federal PDOT e dá outras providências.

BRASIL 2010. Lei $n^{\circ} 12.340$, de 10 de abril de 2010. Dispõe sobre as transferências de recursos da União aos órgãos e entidades dos Estados, Distrito Federal e Municípios para a execução de ações de prevenção em áreas de risco de desastres e de resposta e de recuperação em áreas atingidas por desastres e sobre o Fundo Nacional para Calamidades Públicas, Proteção e Defesa Civil; e dá outras providências, Brasília.

BRASIL 2012a. Lei $n^{\circ}$ 12.608, de 10 de abril de 
2012. Institui a Política Nacional de Proteção e Defesa Civil - PNPDEC; dispõe sobre o Sistema Nacional de Proteção e Defesa Civil - SINPDEC e o Conselho Nacional de Proteção e Defesa Civil - CONPDEC; autoriza a criação de sistema de informações e monitoramento de desastres; altera as Leis nos 12.340, de $1^{\circ}$ de dezembro de 2010, 10.257, de 10 de julho de 2001, 6.766, de 19 de dezembro de 1979, 8.239, de 4 de outubro de 1991, e 9.394, de 20 de dezembro de 1996; e dá outras providências. Diário Oficial da União, Brasília.

BRASIL 2012b. Atualiza a Lei Complementar $n^{\circ}$ 803, de 25 de abril de 2009, que aprova a revisão do Plano Diretor de Ordenamento Territorial do Distrito Federal - PDOT e dá outras providências.

BRASIL 2019a. Lei $N^{0}$ 6.269, de 29 de janeiro de 2019. Institui o Zoneamento Ecológico-Econômico do Distrito Federal - ZEE-DF em cumprimento ao art. 279 e ao art. 26 do Ato das Disposições Transitórias da Lei Orgânica do Distrito Federal e dá outras providências.

BRASIL 2019b. Lei Complementar n. ${ }^{\circ}$ 948, de 16 de janeiro de 2019. Aprova a Lei de Uso e Ocupação do Solo do Distrito Federal - LUOS nos termos dos arts. 316 e 318 da Lei Orgânica do Distrito Federal e dá outras providências.

BITAR, O.Y.; FREITAS, C.G.L.; MACEDO, E.S. 2015. Guia Cartas geotécnicas [livro eletrônico]: orientações básicas aos municípios. São Paulo: IPT - Instituto de Pesquisas de Tecnológicas do Estado de São Paulo, 2015.

CHAND, F. 1999. Environmental geology in urban development. Ninth Regional Congress on Geology, Mineral and Energy Resources of Southeast Asia - GEOSEA ‘98 17 - 19 August 1998 - Shangri-La Hotel, Kuala Lumpur, Malaysia.

COUTINHO, R.Q. (Coord. e Org.) 2013. Parâmetros para a Cartografia Geotécnica e diretrizes para áreas sujeitas a Desastres Naturais, GEGEP/UFPE/MCIDADES, Recife.

CULSHAW, M.G; PRICE, S.J. 2010. The contribution of urban geology to the development, regeneration and conservation of cities. Bulletin of Engineering Geology and the Environment, 70:333-376.

DAVIES, T.C. 2015. Urban geology of African megacities. Journal of African Earth Sciences 110:188-226.

DEARMAN, W.R. 1991. Engineering Geological Mapping. British Library Cataloguing Publication Data, Butterworth e Heinemama, London, UK, $415 \mathrm{p}$.

FELTRIN, T. F.; RAIA JUNIOR, A. 2012. A. Lei 12.608/12 Instrumento de auxílio à gestão da logística humanitária no enfrentamento de desastres causados por fenômenos naturais. Anais do IX Convibra Administração - Congresso Virtual Brasileiro de Administração. 13p

JEFFERIS J.K. 1986. Implications of Geology in Cityand Regional Planning. The Ohio State University, degree of B.S. in Geology, 24 p.

KARROW, P.F., and WHITE, O.L. (1998). Urban Geology of Canadian Cities, Newfoundland, Canada, Geological Association of Canada, Special Paper 42, 500pp.

LEGGET, R.F. 1973. Cities and geology: McGrawHill Book Company, N.Y., 624 p.

MULDR, F.J. 1993. Urban geology in Europe: an overview. Quaternary International, Vol. 20, 10406182(94): 5-11.

OLIVEIRA, B.R. 2018. Cartografia geotécnica de grande escala: estudo de caso setor habitacional Asa Taquari [Distrito Federal. Dissertação de Mestrado, Publicação G.DM-305/2018, Departamento de Engenharia Civil, Universidade de Brasília, Brasília, DF, 144 p.

OLIVEIRA \& MONTICELLI 2018. Geologia de Engenharia e Ambiental. ABGE, 3v.

PAULA, B.L.; CERRI, L.E.S. 2008. Proposta de representação cartográfica para cartas geotécnicas. Revista Geotecnia, 112(março): 11-126.

PELOGGIA, A.U.G. 1997. Delineação e 
aprofundamento temático da geologia do tecnógeno do município de São Paulo. As consequências geológicas da ação do home sobre a natureza e as determinações geológicas da ação humana em suas particularidades referentes a precária ocupação urbana. USP. IG. 288 p.

PRANDINI, F.L., NAKAZAWA, V.A., FREITAS, C.G.L., DINIZ, N.C. 1995. Cartografia geotécnica nos planos diretores regionais e municipais. In: BITAR, O.Y. (Coord.). Curso de geologia aplicada ao meio ambiente. São Paulo: Associação Brasileira de Geologia de Engenharia (ABGE) e Instituto de Pesquisas Tecnológicas (IPT), cap. 4.4, p.187-202.

RODRIGUEZ, S.K. 1998. Geologia Urbana da Região Metropolitana de São Paulo. Tese de Doutoramento - Programa de Geologia Sedimentar - IG/USP. 60p.
SANTOS A.R. 2008. Diálogos geológicos: é preciso conversar com a terra. São Paulo, Em nome da rosa, 2008.

SANTOS, A.R. 2017. Cidades e Geologia: Discussão Técnica e Proposição de Projetos de Lei de Grande Interesse para as Populações Urbanas. Rudder, São Paulo, 136 p.

SHOWSHACK, R. 2014. Scientists Call for a Renewed Emphasis on Urban Geology. Eos, Vol. 95, No. 47, 25 November 2014, 2 p.

TOMINAGA, L.K.; PEJON, O.J.; BASTOS, C.A. 2004. Diagnóstico preliminar da cartografia geotécnica e geoambiental no Brasil. $5^{\circ}$ simpósio Brasileiro de Cartografia Geotécnica e Geoambiental. 16 a 18/11/2004. 20 p. 